保健物理，32(2)，135～138（1997）

《特集：非電離放射線の防護を考える》

\title{
高周波電磁界の健康影響
}

雨 宮 好 文*1

1. はじめに

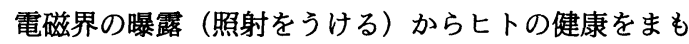
る（電波安全性を保つ）ため，先進諸国はそれぞれ電波 の曝露に関する基準（防護基準）を定める努力をしてき た。それらにおいては，高周波電磁界の生体影響は，主 として熱作用によるというのが共通の認識になってい る。

$\mathrm{X}$ 線， $\gamma$ 線は電離作用により生体組織に影響を与える が，同じく電磁波であっても，電波は発熱作用によって 影響（温度上昇）を与える。作用の相違は全く波長の違 いによる。強力な電波は, 曝露された物体の温度を著し く上げ, 物体に非可逆的変化を与えることは電子レンジ でみるとおりである。防護基準は，電磁界レベル（電波 の強さ）をおさえようというものである。この範囲で, 電磁界レベルがあるしきい值を越えたときに体温上昇と いう影響が生じるが，電磁界を回避すれば体温はもとに 戻る。すなわち，電波によっては蓄積作用がない。電磁 界の熱作用による影響は，他の加熱手段による影響と同 じである。なお， $100 \mathrm{kHz}$ 以下では刺激作用の影響 (例 えば電磁界に曝露されたバスの把手を握るときの電撃） も無視できない。熱作用, 刺激作用のほか, いわゆる非 熱作用についても報告されている。

防護基準として有名なのは米国規格協会 (American National Standards Institute, 略称 ANSI）のものであ り, 1966 年に発表されて以来, 随時見直しも行われ, 多 くの各国基準の下敷きとなってきた。

\section{2. 高周波奄磁界の作用と影電1)}

\section{1 諸 単 位}

電波に曝露された生体が電波の電力を吸収する程度を 示すものとして, 比吸収率 $(\mathrm{SAR}$, 単位は $\mathrm{W} / \mathrm{kg})$ とい

${ }^{* 1}$ 金沢工業大学工学部；石川郡野々市町扇が丘 7-1（テ 921） Faculty of Engineering, Kanazawa Institute of Technology ; 7-1, Oogigaoka, Nonochi-cho, Ishikawa-gun, Ishikawa 921 , Japan.
う量がある。生体の全身にわたり SAR を平均したもの を全身平均 SAR という。生体の局所の微小領域(例えば $10 \mathrm{~g})$ について平均したものを局所 SAR という。.

電波の強さを表すものとして, 電界強度, 磁界強度お よび電力密度 (単位は, それぞれ $\mathrm{V} / \mathrm{m}, \mathrm{A} / \mathrm{m}, \mathrm{mW} / \mathrm{cm}^{2}$ ) がある。例えば, 電力密度が $1 \mathrm{~mW} / \mathrm{cm}^{2}$ の電波とは, 電 界強度が $61.4 \mathrm{~V} / \mathrm{m}$ の電波のことである。電力密度は, 電界強度あるいは磁界強度の 2 乗に比例する。

\section{2 熱作用と生体影䉕}

（1）行動変化 レバーを押して食物を出す訓練を施し たラットを, ある強度以上の電波に曝露すると, ラット はレバーを押すのをやめて体をなめ回す(行動変化)。電 波の曝露を止めると,ラットの行動はもとに戻る。この 行動変化をおこす全身平均 SAR しきい值は $4 \sim 8 \mathrm{~W} / \mathrm{kg}$ であり，動物の種にはあまりよらないとされる。

（2） マイクロ波ヒヤリング マイクロ波のパルスを頭 部に照射すると，その人にはクリック音が聞こえる（マ イクロ波ヒヤリング効果)。この原因は, マイクロ波パル スにより頭蓋骨内に $10 \mu \mathrm{s}$ 程度の短時間内に $10^{-6}{ }^{\circ} \mathrm{C}$ 程 度の急激な温度上昇があり，組織の熱膨張による圧力波 が骨から聴覚器官へと伝わるためであると説明されてい る。マイクロ波ヒヤリング効果は, 電力密度が $0.1 \mathrm{~mW} /$ $\mathrm{cm}^{2}$ (ANSI 基準の電力密度の限界値以下) であっても生 じる。ヒトの健康には影響がないとされる。

（3）白内障 眼に対する白内障発生の研究も多数あ り, 眼球内の温度, 温度勾配および加熱速度がそれをお こす主原因であるといわれる。ウサギの眼の白内障発生 の電力密度しきい值として, $2.45 \mathrm{GHz}$ 電波の 100 分間 の曝露で $150 \mathrm{~mW} / \mathrm{cm}^{2}$ (局所 SAR は $138 \mathrm{~W} / \mathrm{kg}$ ) という データがある。例えばこの周波数での ANSI 基準の限界 值は $8.17 \mathrm{~mW} / \mathrm{cm}^{2}$ (1992 年, 管理条件)であるので, 基 準を順守するかぎり白内障発生はない。

（4）胎仔奇形 子宮温度が $39^{\circ} \mathrm{C}$ より高くなると胎仔 に悪影響を与える。動物で胎仔奇形を生じると報告され 
た最低全身平均 SAR は $10.8 \mathrm{~W} / \mathrm{kg}$ (体温が $41.5^{\circ} \mathrm{C} に$ なった）である。各国基準の全身平均 SAR 限界值は 0.4 $\mathrm{W} / \mathrm{kg}$ であるので, 基準を順守するかぎり胎仔奇形を生 じることはない。

（5）免疫系 免疫系への影響は，加熱による一般的な ストレス反応から生じると見られる。基準を順守するか ぎり,ヒトの体温上昇は $0.1 \sim 0.4^{\circ} \mathrm{C}$ と見積もられ, 免疫 系への影響はないと思われる。

\section{3 刺激作用と生体影響}

（1）接触電流 電波の曝露を受けている非接地の金属 物体にヒトが接触したとき, 接触電流が流れ電撃を受け る。周波数が低い電流ほど電撃の程度は大きい。

（2）体内誘起電流 外部電磁界によって体内に誘起さ れる電流が, 脳の神経活動, 心筋の活動等による内因性 電流に比しある大きさ（周波数 $f$ が $1000 \mathrm{~Hz} \sim 10 \mathrm{MHz}$ につき $\left.f / 1000\left[\mu \mathrm{A} / \mathrm{cm}^{2}\right]\right)$ になると, 神経系, 視覚系細 胞の興奮を引き起こす。周波数が低い電流ほど興奮の程 度が大きい。

\section{4 非熟作 用}

刺激作用以外の非熱作用のデータは防護基準には取り 入れられていない。理由は，その影響の確認が困難であ るとか, in vitro (試験管内) で観察できた現象が in vivo (生体内)でどう現われるか不明であるとかにある。この ことは，非熱作用があるとしても，その影響の程度は見 えないくらい微弱であることを意味する。

（1）細胞レベルでの現象 細胞レベルでの研究では, 電波の曝露によってウサギ，イヌ，ヒトの細胞の細胞膜 の陽イオン透過性の変化（しきい值はマイクロ波で約 $100 \mathrm{~V} / \mathrm{m}$ ), ウサギの赤血球の溶血（しきい値は $100 \mathrm{MHz}$ で約 $400 \mathrm{~V} / \mathrm{m}$ ), ラットの脳エネルギー代謝の変化(しき い值は $200 \mathrm{MHz}$ 他で 3〜 $5 \mathrm{~V} / \mathrm{m}$ ) 等があげられている。 しかし，この in vitro の現象が in vivoではどう現われ るかという研究までは進んでいない。

(2) カルシウムイオン流出 ヒヨコ, ネコから摘出し た大脳皮質を，低周波で変調した UHF，VHF に曝露す るとカルシウムイオンが流出する, という in vitro の実 験結果は有名である。カルシウムイオンは情報伝達, 免 疫系の動作, 細胞の増殖等にも欠かせない。イオン流出 は, 例えば変調周波数では 6 25 Hz, 電力密度では $0.1 \sim 1.0 \mathrm{~mW} / \mathrm{cm}^{2}$ のときに限って生じるという変調周 波数および電波強度の「空」があるというのが特幑的で ある。ELFである $45 \mathrm{~Hz}, 50 \mathrm{~Hz}, 60 \mathrm{~Hz}$ の界(5〜 $50 \mathrm{~V} /$ $\mathrm{m})$ でも類似の現象が起きる。これらの現象のメカニズム は明らかでなく，またin vivoではどう現われるかとい う研究までは進んでいない。
（3）低レベル電波の曝露実験 熱作用が実質的にない 低レベルの電波曝露において，なにか非熱作用による悪 い影響が現われるか調べた 1986 年頃話題になった有名 な実験がある。これはワシントン大学のグループが米空 軍の資金援助を得て行ったものであり，マイクロ波 2.45 $\mathrm{GHz}, 0.5 \mathrm{~mW} / \mathrm{cm}^{2}$ (当時の防護基準の限界値の $1 / 10$ と いう低レベル，全身平均 SAR は $0.2 \sim 0.4 \mathrm{~W} / \mathrm{kg}$ ）の 25 か月間の曝露を受けたラットでは, 悪性腫瘍が 100 匹中 18 匹に生じたのに対し, 曝露を受けなかった対照群では 5 匹であった。しかし, 曝露群での悪性腫瘍発生率は, そ の血統のラットに期待される本来の腫崵発生率にほほ等 しいことから，マイクロ波曝露の非熱作用による生体影 響があったとはいえない, とその報告者らは結論してい る。

\section{3. 各国の防護基準と実測例 ${ }^{1)}$}

\section{1 各国基準值の比較}

各国の防護基準では, 周波数に対する電界強度, 磁界 強度の限界值（許容值）が表の形で与えられている。こ れを図示すると第 1 図のような折れ線カーブとなる。こ こには, VDE (独), ANSI, IRPA, 郵政省, 旧ソ連の 基準の電界強度の限界値を示す。この限界值は，外部電 磁波源によって照射されたある空間内の電界強度がこの 值以下ならば，そこにヒトが入っても安全であることを 示す。携帯電話使用者のように自分が発射した電波を受 ける場合については，別扱いである (4 章参照)。

図において，旧ソ連の基準の限界值は米国のそれより かなり低いことが見える。理由は，米国は実験的アプ ローチの結果を基礎とするのに対し，旧ソ連は疫学調査 の結果を重視することにある。

各国基準の限界値には，その国の経済的社会的問題に 対する重点の置き方を反映して，一般に差異が存在す

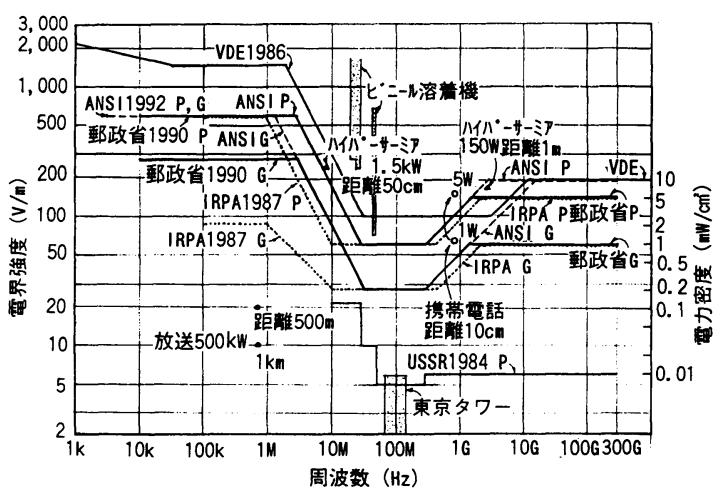

第 1 図各種電波源の電界強度実測値と各国の防護 基準 
る。図において，例えば周波数 $10 \mathrm{MHz}$ では, VDE, ANSI, 郵政省およびIRPA の記号 P の限界値は, それ ぞれ $300,184,184$ および $61.4 \mathrm{~V} / \mathrm{m}$ となっている。防 護基準が定める限界值とは，このような性格のものであ るので，実測值が限界值をわずかでも越えると安全でな いと考えたり, 特定の職場で, この限界值の何分の 1 か の值を新たな規制値として定めたりする等のことは無意 味である。

\section{2 実 測 例}

第 1 図には, ハイパーサーミア機器, 高周波ビニール 溶着機, 携帯電話などの電界強度の実測例も示す。高周 波ビニール溶着機周辺の電界強度がとびぬけて大きい。 携帯電話の電界強度も大きいが, 規準については 4 章を 参照。

\section{3 基準の根拠}

(1) 職業人と一般人の区別 一般人の電磁界強度の限

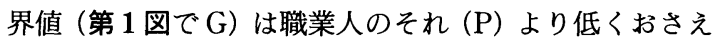
ている。この区別の理由は次のことにある。職業人は健 康な大人で, 電磁界に曝露されているとの認識をもち, 必要があれば電磁界を避けることができ，1日 8 時間だ け曝露を受ける。一般人は, 病者も弱者もあり, 小児も 老人もあり,電磁界に曝露されていることを知らず, 1 日 24 時間曝露を受ける恐れがある。一般人に対しては, そ れだけ簃しく曝露が制限されているわけである。

（2）根拠 第 1 図で我が国の基準（指針）（1990 年）に ついて説明する。周波数 $3 \mathrm{MHz}$ 以下の範囲は, バス, ト ラックの把手を握ったときの電撃による障害を防ぐため の限界值 (指針值ともいう) である。周波数 $3 \mathrm{MHz} \sim 300$ $\mathrm{GHz}$ の範囲は, 全身平均 SAR が $0.4 \mathrm{~W} / \mathrm{kg}$ に等しくな る無擾乱界(測定対象箇所に人体が存在しないときの界) の限界值である。全身平均 SAR の限界値 $0.4 \mathrm{~W} / \mathrm{kg}$ は, 動物の行動変化が現われる全身平均 SAR のしきい値 $4 \sim 8 \mathrm{~W} / \mathrm{kg}$ の $1 / 10$ である（ヒトの基礎代謝量をもとに 計算すると体温は $0.1 \sim 0.4^{\circ} \mathrm{C}$ 上昇すると想定される)。

しかしSAR の実測は難しいので, 限界值としては実 測が容易で慣用的な電磁界強度をもって与えることが必 要である。そのためには, 電磁界強度を全身平均 SAR と きちんと対応づけすることが必要である。これを実行す るためのモデルとして, 完全導体大地上の空間中で大地 に垂直な電界をもつ平面波の界を考える。その界の中に 人体をもちこむとき,それにおける全身平均 SAR が 0.4 $\mathrm{W} / \mathrm{kg}$ に等しくなる無摄乱界の強度を, 電磁界強度の限 界值であると定めているのである。また, 例えばビニー ル溶着機, ハイパーサーミア機器の近傍などでは, 界は 上記の平面波とは異なる。この場合の対処方法を, 補助
指針によって定めている。

周波数 $30 \sim 300 \mathrm{MHz}$ の範囲で限界值が谷 $(61.4 \mathrm{~V} / \mathrm{m})$ になっている。理由は, この範囲で人体の共振現象があ るので, 全身平均 SAR $0.4 \mathrm{~W} / \mathrm{kg}$ に押さえるには, 界 強度を他の周波数領域でのそれょり低い値に制限する必 要があるからである。

\section{4. 携帯電話と規準}

\section{1 我が国の基準（1990 年）}

職業人, 一般人の区別なく, 周波数 $100 \mathrm{kHz} \sim 3 \mathrm{GHz}$ で出力 $7 \mathrm{~W}$ 以下の電磁放射源（例えば携帯電話）の通常 の使用状態では, 電磁界強度限界值(第 1 図の折れ線カー ブ）を越えても安全であると補助指針が述べている。こ れは ANSI 1982 年基準の踏襲である。局所 SAR の限界 值は $8 \mathrm{~W} / \mathrm{kg}$ であるとされており,この場合に頭部内の 局所 SAR がこの值を越えないことから安全である。な お, 我が国で普通に使われている携帯電話の出力は 0.6 $\mathrm{W}(900 \mathrm{MHz}, 1.5 \mathrm{GHz})$, コードレス電話は $10 \mathrm{~mW}$ (250 MHz，400 MHz) 程度である。

\subsection{ANSI 基準（1992 年）}

職業人と一般人（ANSI では管理条件と非管理条件と いう）とを区別し，前者では， $100 \mathrm{kHz} \sim 450 \mathrm{MHz}$ で出 力 $7 \mathrm{~W}$ 以下, $450 \sim 1500 \mathrm{MHz}$ で $7 \times\{450 / f(\mathrm{MHz})\} \mathrm{W}$ 以下の無線機は $2.5 \mathrm{~cm}$ まで接近してよい（一般人では, この出力の $1 / 5)$, としている。このとき頭部内の局所 $\mathrm{SAR}$ が $8 \mathrm{~W} / \mathrm{kg}$ を越えないのである。

\subsection{ICNIRP ステートメント $(1996 \text { 年 })^{2)}$}

1987 年 IRPA 基準では, $7 \mathrm{~W}$ 以下の無線機は，その基 準から除外する, とされていた。その後, 携帯電話と居 住地域での基地局送信機の使用が著しく増加したことに かんがみ，1996 年 4 月 ICNIRP ステートメントを公表 した。その結論の 9 項目のうちで, 使用者にとって重要 である 2 項目を次に示す。

(1) 一般公衆が使用する携帯電話に対しては, 頭部内 の局所 SAR は，その組織の任意の質量 $10 \mathrm{~g}$ にわたる平 均值を $2 \mathrm{~W} / \mathrm{kg}$ に制限するべきであると ICNIRP は勧 告する。

（2）無線電話の使用は，干涉の起きる恐れのない地域 に限定するべきである（例えば，病院の集中看護室およ び類似の場所から十分離れる)。

5. おわりに

高周波電磁界の健康影響問題は 1940 年代後半に始ま る。長年の研究成果の集積の結果から防護基準が定めら れた。ここで携帯電話に関する 4.3 節(1) (2)の ICNIRP ステートメントに対する筆者の意見と補足を述べて稿を 閉じたい。 
（1）局所 SAR を $2 \mathrm{~W} / \mathrm{kg}$ に制限するべきであるとい われても, 使用者には, 自分の使用形態が果たして $2 \mathrm{~W} /$ $\mathrm{kg}$ 以下であるか, あるいは越えているかがわからない。 各製造者は, 各携帯電話機ごとに使用時の局所 SAR を 実測して置くべきであろう（予想される訴訟問題に備え るためにも)。例えば電子レンジでは, 器体から $5 \mathrm{~cm}$ は なれて $5 \mathrm{~mW} / \mathrm{cm}^{2}$ 以下であるべきことが我が国では電 気用品取締法で定められ, 製造者は全数実測検查してい る。

（2）我が国の不要電波問題対策協議会 (平成 8 年 4 月) の暫定指針は, 携带電話 $(1 \mathrm{~W}$ 以下) は埋込み型心臓ぺー
スメーカから $22 \mathrm{~cm}$ 以上, 自動車電話とショルダーホン （2〜 $5 \mathrm{~W}$ 以下）のアンテナは $30 \mathrm{~cm}$ 以上離すように具体 的に定めている。

\section{参考文 献}

1）雨宮好文；高周波電磁界の生体影響と防護規準, 電 子情報通信学会誌, 78，466-475（1995）.

2) ICNIRP ; Health issues related to the use of hand-held radiotelephones and base transmitters, Health Physics, 70, 587-593 (1996). 